\title{
APPLICATION OF RAW SECONDARY METABOLITES FROM TWO ISOLATES OF Trichoderma harzianum AGAINST ANTHRACNOSE ON RED CHILI PEPPER IN THE FIELD
}

\author{
Loekas Soesanto, Endang Mugiastuti, Agus Suyanto, \& Ruth Feti Rahayuniati \\ Faculty of Agriculture, Universitas Jenderal Soedirman, Indonesia \\ Jl. Dr. Suparno, Karangwangkal, Purwokerto 52123 \\ E-mail: lukassusanto26@gmail.com
}

Manuscript received: 4 November 2017; Revision accepted: 11 Maret 2020

\begin{abstract}
Application of raw secondary metabolites from two isolates of Trichoderma harzianum against anthracnose on red chili pepper in the field. Anthracnose on red chili pepper is one of the highly damaging diseases that difficult to control by pesticides. This study aimed to determine the effect of raw secondary metabolites isolated from two isolates of Trichoderma harzianum towards anthracnose as well as the growth and yield of red chili pepper plants in the field. The research used a randomized block design with five treatments and seven replicates. The treatments tested were control, raw secondary metabolites of T. harzianum T10 and T213, and their combination. The observed variables were incubation period, disease intensity, the late population density of $T$. harzianum, plant height, root length, fresh and dry weight of the plant and root, flowering time, number of fruits per plant, fresh weight of fruit, and phenolic compound content analysis. The result showed that the raw secondary metabolites from the combination of the two T. harzianum isolates were the best treatments that could lengthen the incubation period and decrease the disease intensity as 30.2 and $87.05 \%$, respectively. However, these applications could not increase the growth components; while for the yield components, the application could improve the number of fruits per plant and fresh weight of fruit as 15.33 and $34.53 \%$, respectively.
\end{abstract}

Key words: anthracnose, red chili pepper, raw secondary metabolites, Trichoderma harzianum

\section{INTRODUCTION}

Red chili pepper (Capsicum annuum L.) is the horticultural plants that has a high selling value and needed in daily life for Indonesian. The need for red chili pepper is always increase along with the population growth, so that the business opportunity is still promising (Malen et al., 2011). The productivity of red chili pepper in Indonesia has increased from 2010 to 2014. In 2013 the productivity of red chili pepper had reached 8,16 tons/ha and became 8,37 tons/ha in 2014 (BPS, 2015).

One of the major concerns in the production of red chili pepper is anthracnose (patek, local name). According to Pakdeevaraporn et al. (2005) and Semangun (2007), anthracnose caused by Colletotrichum capsici (Syd.) EJ Butler \& Bisby. The yield loss due to anthracnose could reach $60 \%$ or more (Pakdeevaraporn et al., 2005), it can destroy crops up to $90 \%$ especially during the rainy season (Agromedia, 2007). Typical anthracnose symptoms on red chili pepper were sunken necrotic tissues, with concentric rings of acervuli. The visible symptoms on red chili pepper could decrease its selling point (Manandhar et al., 1995).

The effective disease management strategy of anthracnose on red chili pepper is ongoing research; however the commercial cultivars that are resistant to anthracnose have not yet been developed (Than et al., 2008). The alternative control to overcome anthracnose infection was by utilizing microorganisms or using antagonistic agents, which known to inhibit the development of pathogens (Aktar et al., 2009).

Two isolates of Trichoderma harzianum, the ginger and shallot isolates (Soesanto et al., 2011) were isolated and identified to be used in this study. Latifah et al. (2011) reported that the treatment of shallot isolate before the inoculation of Fusarium sp. showed the effect on growth with the number of roots reaching 192.33 or an increasing of $57.45 \%$ than the control. While the treatment of ginger isolates before inoculation showed the effect on root length reached $26.29 \mathrm{~cm}$ or increased by $17.67 \%$ compared to control.

The use of raw secondary metabolites isolated from $T$. harzianum is one of the alternative that can be 
used to overcome anthracnose on red chili pepper (Soesanto et al., 2015). This study aimed to understand the effect of raw secondary metabolites application from two T. harzianum isolates, both single and combined to anthracnose as well as their effects on the growth and yield of red chili pepper plants in the field.

\section{MATERIALS AND METHODS}

Research Site. This research was carried out in a red chili pepper field with altitude $225 \mathrm{~m}$ above see level and ultisol soil type in Banteran village, Sumbang, Banyumas. The study was conducted from September to December 2014.

Preparation of $\boldsymbol{T}$. harzianum Isolates. Two T. harzianum isolates used in this study were T. harzianum $\mathrm{T} 10$ isolated from the ginger rhizosphere (Soesanto et al., 2005) and T. harzianum T213 isolated from the shallot rhizosphere (Santoso et al., 2007). The isolates were cultured on the potato dextrose agar (PDA) and propagated in broken maize grains and chicken manure medium. Propagation in broken maize grains medium was conducted by adding two cork borrers ( 6 $\mathrm{mm}$ in diameter) of $T$. harzianum culture to $50 \mathrm{~g}$ of broken maize grains medium, then incubated at room temperature. While propagation in chicken manure was conducted by adding $50 \mathrm{~g}$ of $T$. harzianum T10 and T213 culture in broken maize grains medium each to $1 \mathrm{~kg}$ of chicken manure medium, then stirred and incubated in a bucket under closed conditions (Soesanto et al., 2014).

Preparation of Colletotrichum capsici. Colletotrichum capsici was isolated and identified from red chili pepper showing anthracnose symptom. The C. capsici was cultured on the PDA and incubated for seven days at room temperature (Waller et al., 2001). The conidia then harvested by adding $10 \mathrm{~mL}$ of sterile water in the culture and the density was calculated to $10^{6}$ conidium $/ \mathrm{mL}$ using haemocytometer (Herwidyarti et al., 2013). Spraying was done one day before the treatment of raw secondary metabolites.

Preparation of $T$. harzianum Raw Secondary Metabolites. Raw Secondary Metabolites of $T$. harzianum were isolated by using a mix medium of rice water and coconut water in a ratio of $8: 2$, then added with $10 \mathrm{~g} / \mathrm{L}$ sugar (Soesanto et al., 2014). The medium then boiled, filtered, and sterilized using autoclave at $121{ }^{\circ} \mathrm{C}$ for $30 \mathrm{~min}$. After the medium was reached the room temperature, two mycelia plug of each isolates were added separately, then shaked using orbital shaker for seven days at room temperature. The population density of T. harzianum was calculated using haemocytometer to determine the ability of raw secondary metabolites produced. Furthermore, the solution of T. harzianum was filtered using Whatman filter paper 42 to separate the fungal propagules.

Preparation of Red Chili Pepper Seedlings. The seeds of Astina F1 variety (Panah Merah) were grown in seedling media filled with $100 \mathrm{~g}$ of soil inside a polybag. After the red chili pepper seedlings were 14 days old, the NPK fertilizer was given around $2 \mathrm{~g}$ per polybag and 30-day-old seeds ready to be transplanted.

Land Preparation. The land used was $110 \mathrm{~m}^{2}$ with 10 beds measuring $1 \times 10 \mathrm{~m}$. The distances between beds were $1 \mathrm{~m}$ and the height of beds were $50 \mathrm{~cm}$. Spacing used were $50 \times 50 \mathrm{~cm}$. The beds were covered with black silver plastic mulch, perforated with a planting hole diameter of $10 \mathrm{~cm}$. Before transplanting, the application were carried out according to the specified treatment. The use of each $T$. harzianum isolate in chicken manure medium was $50 \mathrm{~g} /$ planting hole as basic fertilizer according to treatment. After being treated, the seeds were planted in each planting hole according to treatment.

Experimental Design. The study was conducted based on a randomized block design consisting of four treatments: (1) control (sterile water), (2) raw secondary metabolite of T. harzianum T10, (3) raw secondary metabolite of $T$. harzianum $\mathrm{T} 213$, (4) combined raw secondary metabolites of T. harzianum T10 and T213. Each treatment was repeated seven times. Each treatment consisted of six plants, so that 168 experimental plants were used.

\section{Application of T. harzianum Raw Secondary} Metabolites in the Field. The application was conducted by spraying the raw secondary metabolites once a week starting since the flowering of red chili pepper plants. Each T. harzianum isolate and its combination were given $50 \mathrm{~mL} /$ plants by spraying it on the flower and all plants. Furthermore, the culture of $T$. harzianum was sprayed $5 \mathrm{~mL} /$ plants using handsprayer that on the flowered and fruited plants.

Observation. The observed variables on this study were the pathosystem component, plant growth, yield, and tissue analysis. The pathosystem component were consisted of incubation period and disease intensity, while 
the growth component consisted of plant height, root length, fresh plant weight, fresh root weight, dry plant weight, and dry root weight. The yield component consists of flowering time, number of fruits per plant, and fresh fruit weight, while tissue analysis consists of tannins, saponins, and glycosides (Chairul, 2003). The intensity of disease was calculated by the following formula:

$$
\mathrm{DI}=\frac{\sum(\mathrm{n} \times \mathrm{v})}{\mathrm{Z} \times \mathrm{N}} \times 100 \%
$$

DI = intensity of anthracnose

$\mathrm{n}=$ number of damaged fruits in each attack category

$\mathrm{v}=$ the value of each attack category

$\mathrm{Z}=$ highest damage category value

$\mathrm{N}=$ number of observed fruits

The scale value of anthracnose was based on the scale of spots on red pepper attacked by pathogen as follows (Herwidyarti et al., 2013):

$0=$ healthy fruit

$1=$ Spots on red pepper $1-20 \%$

$2=$ Spots on red pepper $21-40 \%$

$3=$ Spots on red pepper $41-60 \%$

$4=$ Spots on red pepper $>60 \%$

The tannins test was identified by reacting $\mathrm{FeCl}_{3}$ to extract $10 \mathrm{~g}$ of fruit with $80 \%$ ethanol, and given 5 drops of $1 \% \mathrm{NaCl}$ solution then was observed the level of color change compared to control.

The saponins test is froth test using lerak as a control. Procedures for testing were $2 \mathrm{~mL}$ of plant extract was put into a test tube then $10 \mathrm{~mL}$ of water was added, covered, and shaken for $30 \mathrm{sec}$, then left for $30 \mathrm{~min}$. Observations were made on the height of the froth formed compared to control.

The glycocides test using Keller Kiliani reagent was extracts of plant material (fruit) were dried with a water bath, then washed with hexane and added $3 \mathrm{~mL}$ of $\mathrm{FeCl}_{3}$ reagent, stirred and dropped $1 \mathrm{~mL}$ of concentrated sulfuric acid solution, then left for a minutes until the color changes. Observations were made on the level of color density compared to control. Observation of the level of sensitivity and high froth were qualitatively written with the symbol + (a little), ++ (rather a lot), and +++ (a lot).

Data Analysis. Data were analyzed by anova and follewed by Duncan's multiple range test (DMRT) at $5 \%$.

\section{RESULTS AND DISCCUSSION}

Pathosystem Component. Based on the statistical analysis, the treatment of $T$. harzianum raw secondary metabolites had a significant effect on the disease incubation period and intensity in red chili pepper compared to control (Table 1). In this case, the treatment of $T$. harzianum raw secondary metabolites namely $\mathrm{T} 10, \mathrm{~T} 213$ or a combination could delay the incubation period.

The increase of incubation period by T. harzianum T10 was $23.1 \%$, while $T$. harzianum $\mathrm{T} 213$ and the combination were $29.2 \%$ and $30.2 \%$ compared to controls. This was due to the many complexities contained in raw secondary metabolism that can inhibit the growth of pathogens. Some of these compounds are the chitinase enzyme and $\beta-1,3-$ glucanase. This is consistent with Sulistiyono's research (2014), that all T. harzianum isolates tested produced chitinase, $\beta$-1,3-glucanase, protease, and cellulase enzymes among $0.171-0.335 ; 8.868-10.256 ; 9.738$ 12.952 and 5.504-5.924 U/mL, respectively.

Elad et al. (1982) showed that isolates of T. harzianum were found differently in the level of the hydrolysis enzyme produced. Glucanase activity increases to $67 \%$ when fungi were grown on a mixture of laminarin and glucose (3:1, v/v). Kumar et al. (2012) also reported that the activities of chitinase and $\beta-1,3-$ glucanase were found in all Trichoderma isolates in the growing medium. $T$. viride was noted to have the highest chitinase activity while $T$. harzianum had the

Table 1 . Treatments of $T$. harzianum raw secondary metabolites on the pathosystem component

\begin{tabular}{lccc}
\hline \multicolumn{1}{c}{ Treatments } & $\begin{array}{c}\text { Incubation } \\
\text { period (DAI) }\end{array}$ & $\begin{array}{c}\text { Disease } \\
\text { intensity (\%) }\end{array}$ & $\begin{array}{c}\text { The effectivities of } \\
\text { disease intensity (\%) }\end{array}$ \\
\hline Control & $41.53 \mathrm{~b}$ & $15.99 \mathrm{a}$ & - \\
T. harzianum T10 & $54.00 \mathrm{a}$ & $3.08 \mathrm{~b}$ & 80.74 \\
T. harzianum T213 & $59.26 \mathrm{a}$ & $2.91 \mathrm{~b}$ & 81.80 \\
Combination of $T$. harzianum T10 and T213 & $59.46 \mathrm{a}$ & $2.07 \mathrm{~b}$ & 87.05 \\
\hline
\end{tabular}

The numbers in the same column followed by the same letters are not significantly different based on DMRT at the 5\% level; DAI: day after inoculation. 
highest $\beta$-1,3-glucanase activity. The most important thing is Trichoderma spp. has the ability of antagonists to be efficiently higher by secreting lysis enzymes in the form of chitinase and $\beta$-1,3-glucanase extra-cells. The lysis enzyme breaks down the polysaccharide cell wall into short oligomers and facilitates hyperparasite for penetration into the cytoplasm of the target fungal pathogen (de la Cruz et al., 1995; Viterbo et al., 2002; Markovich \& Kononova, 2003).

Based on Table 1, the raw secondary metabolites of two T. harzianum isolates namely T10 and T213 could increase the incubation period compared to controls. In this case proved that the combination of two or more antagonistic isolates gave better results when applied in the field than control. This is consistent with Thangavelu \& Gopi's (2015) that the combined application of endophytic isolates and the rhizosphere of Trichoderma sp. could suppress Fusarium wilt and improve the growth of banana plants in the greenhouse. Sandheep et al. (2013) also reported that the combination of $T$. harzianum and Pseudomonas fluorescens could increase the growth of vanilla plants better than a single application.

Data on disease intensity (Table 1) showed that there were a decrease in anthracnose intensity in red chili pepper due to the treatment of the raw secondary metabolite T. harzianum. The combined treatment of T. harzianum was able to reduce the disease intensity of anthracnose up to $87.05 \%$ compared to control. This condition was in line with an increase in the incubation period (Table 1), which was thought because of more complete ability of the two T. harzianum raw secondary metabolites isolates, both by their own mechanism and by increasing plant resistance.

Component of Growth. Based on statistical analysis, it showed that the components of plant growth treated by $T$. harzianum $\mathrm{T} 10$ showed results that were not different compared to control. This indicated that the treatment had no significant effect on plant growth; while the application of $T$. harzianum T213 and the combination showed a negative effect on plant growth components. This can be seen from the significant decrease in plant growth components after being treated with T213 and their combination (Table 2). According to Vinale et al. (2012), raw secondary metabolites of Trichoderma at low concentrations had optimal activity as auxin which can stimulate growth, whereas at high doses it can act as an inhibitor.

Application of $T$. harzianum raw secondary metabolites can suppress anthracnose development on red pepper, but had not been able to increase growth

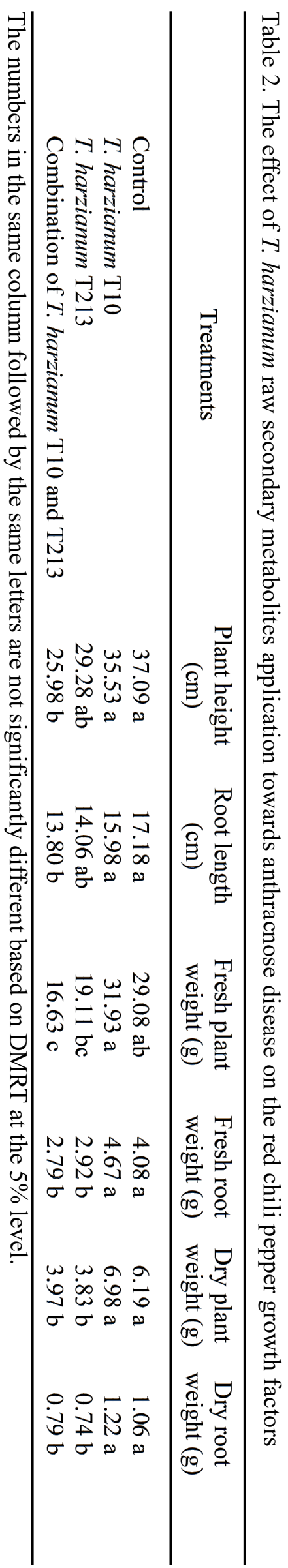


components (plant height, root length, fresh plant weight, dry plant weight, fresh root weight, and dry root weight) compared to control (Table 2). This is presumably due to the lack of growth hormone content in the raw secondary metabolite of $T$. harzianum.

The ability of the raw secondary metabolite $T$. harzianum is highly dependent on the T. harzianum in nature. This is in accordance with Saravanakumar et al. (2017), that Trichoderma strains vary based on environmental impacts, host-pathogen specificity and stability. Trichoderma spp. reported can produce IAA hormones and indole compounds such as indole-3ethanol, indole-3-acetaldehyde, and indole-3-carboxaldehyde as part of its metabolism (Contreras-Cornejo et al., 2009; Contreras-Cornejo et al., 2011). It was further reported by Contreras-Cornejo et al. (2016), that some Trichoderma strains impacted root branching and increased plant canopy biomass as a result of cell division and expansion due to the presence of tub-auxin fungal compounds. According to Heddy (1986), the presence of auxin was greatly influenced by the presence of sunlight. The presence of sunlight with high intensity can inhibit and damage the work of auxin. Vandenbussche et al. (2003) reported that the decrease in light intensity along with an increase in hormone production including ethylene.

Component of Yields. Based on Table 3, the application of $T$. harzianum raw secondary metabolites could increase the yield of red pepper. Although the flowering time of red chili pepper treated with T. harzianum raw secondary metabolites was longer compared to control, but the treatment of $T$. harzianum raw secondary metabolites could increase the number of fruits per plant and fresh fruit weight.

Combined treatment of $T$. harzianum $\mathrm{T} 10$ and T213 raw secondary metabolites showed a longer flowering time compared to control and a single treatment. This was consistent with Table 2 that the inability of T. harzianum isolates produced the cytokinin hormone that affected flowering. In addition, the presence of high sunlight intensity in the field can affect hormone production including flowering hormones (Heddy, 1986).

Although the flowering time was longer, the application of T. harzianum raw secondary metabolites, both single and combined could increase the number of fruits per plant and the fresh weight of fruit (Table 3). The highest increase in number of fruits in the treatment of $T$. harzianum T10 was $26.2 \%$ compared to controls. Meanwhile, the highest increase in fresh fruit weight in combined treatment was $34.54 \%$ compared to controls

This proved that the raw secondary metabolites from combination of two T. harzianum isolates could increase the yield of red chili pepper which was in line with the highest decrease in disease intensity (Table 1). In this case, it was thought because of the lack of anthracnose pathogens in red pepper plants due to the application of the T. harzianum raw secondary metabolite.

The results of this study were supported by reports that $T$. harzianum was conventionally able to control several plant diseases, including rhizome rot in ginger (Amalia et al., 2004; Soesanto et al., 2005), leaf blight on rice (Susilo et al., 2005; Waluyo et al., 2005), rhizome rot in aromatic ginger (Prabowo et al., 2006), Fusarium wilt in chili (Utami et al., 2019), moler in red onion (Santoso et al., 2007), and Fusarium wilt in gladiolus corms (Wardhana et al., 2009). In addition, the application of $T$. harzianum raw secondary metabolites can directly influence plant pathogens (Vinale et al., 2008) or indirectly on plants mediated by increased plant nutrition (Shoresh \& Harman, 2008).

Qualitative Tissue Analysis. Based on the results of a qualitative tissue analysis (Table 4), the application of T. harzianum raw secondary metabolites can increase the content of phenol compounds in the red pepper plant tissue. Almost all treatments of $T$. harzianum raw secondary metabolites, both single and combined isolates

Tabel 3. The effect of T. harzianum raw secondary metabolites application towards anthracnose on the red chili pepper yields

\begin{tabular}{lccc}
\hline \multicolumn{1}{c}{ Treatments } & $\begin{array}{c}\text { Flowering time } \\
\text { (day) }\end{array}$ & $\begin{array}{c}\text { Number of fruits } \\
\text { per plant }\end{array}$ & $\begin{array}{c}\text { Fresh weight of fruit } \\
(\mathrm{g})\end{array}$ \\
\hline Kontrol & $28.00 \mathrm{a}$ & $3.81 \mathrm{bc}$ & $23.71 \mathrm{bc}$ \\
T. harzianum T10 & $30.56 \mathrm{ab}$ & $5.23 \mathrm{a}$ & $34.70 \mathrm{ab}$ \\
T. harzianum T213 & $31.72 \mathrm{ab}$ & $3.98 \mathrm{abc}$ & $25.53 \mathrm{abc}$ \\
Combination of T. harzianum T10 and T213 & $33.93 \mathrm{~b}$ & $4.50 \mathrm{ab}$ & $36.22 \mathrm{a}$ \\
\hline
\end{tabular}

The numbers in the same column followed by the same letters are not significantly different based on DMRT at the $5 \%$ level. 
Table 4. The content of phenol qualitatively red pepper plants in testing the raw secondary metabolite T. harzianum to control anthracnose

\begin{tabular}{lcccc}
\hline & Treatments & Glycosides & Saponins & Tannins \\
\hline Controls & ++ & + & ++ \\
T. harzianum T10 & ++ & +++ & ++ \\
T. harzianum T213 & +++ & +++ & + \\
Combination of T. harzianum T10 and T213 & ++ & ++ & +++ \\
\hline
\end{tabular}

$+=$ a little, $++=$ rather a lot, dan $+++=$ a lot.

were able to increase the content of phenol compounds qualitatively compared to controls. This is in line with the results of anthracnose intensity (Table 1).

The increase in phenol compounds in red pepper plants qualitatively will affect the increase in plant resistance to pathogen attack. Phenol compounds in plants play a role in the mechanism of plant resistance to disease. If phenol compounds is high, then the plant has a high resistance to disease infection. The low content of tannins in the treatment of $T$. harzianum $\mathrm{T} 213$ was thought to have the presence of compounds that decomposed tannins. According to DeRito \& Madsen (2009), some Trichoderma spp. was able to degrade phenol compounds. In general, all treatments had ability to increase total phenol compounds (combined glycosides, saponins, and tannins). This is in line with Nawrocka et al. (2018), that the application of T. atroviride showed a remarkable increase in the concentration of 23 phenols which included hydroxybenzoic acid, cinnamic acid, catechin, flavonol, flavone, and flavanone. Brotman et al. (2012) and Contreras-Cornejo et al. (2016) stated that Trichoderma spp. can control the roots of mono- and dicotyledonous plants, which can cause real changes in plant metabolism, hormone content, soluble sugars, phenol compounds and amino acids.

Phenol compounds act as defense when stressed to the environment, such as light, low temperatures, pathogen infections, herbivores, and nutrient deficiency, which can cause increased production of free radicals and other oxidative species in plants (Lattanzio, 2013). Lin et al. (2016) said that phenol compounds can act as antioxidants, structural polymers (lignin), attractants (flavonoids and carotenoids), UV protectors (flavonoids), signal compounds (salicylic acid, flavonoids), and defense compounds (tannins, phytoalexin). Vallad \& Goodman (2004) also said that raw secondary metabolite, such as alkaloids, phenols, flavonoids, glycosides, and phytoalexins are toxic and inhibit the growth of pathogens so that can affect plant resistance. This is in line with Wachjadi et al. (2013), that phenol compounds in plants was directly related to the level of plant resistance to disease infection. Soesanto \& Rahayuniati (2009) also stated that application of $T$. koningii, $T$. harzianum and Gliocladium virens could increase the glycoside, tannin and saponin in banana seedlings qualitatively.

\section{CONCLUSION}

Raw secondary metabolites from the combination of the two T. harzianum isolates were the best treatments for controling anthracnose on red pepper, which was shown by a longer incubation period and reduced disease intensity by 30.2 and $87.05 \%$, respectively. However, the application of raw secondary metabolites had not been able to increase the growth component; while for the yield component, the treatments were able to increase the number of fruits per plant and fresh weight of fruit respectively by 15.33 and $34.54 \%$.

\section{ACKNOWLEDGMENTS}

The authors would like to thank the Director of Higher Education, Directorate General of Higher Education, Ministry of Education and Culture of the RI for financial support through the Batch III Competency Grant 2015. The authors also would like to thank Sri Mordaningsih and C. Basir (alm) for their technical assistance.

\section{REFERENCES}

Agromedia. 2007. Budidaya Cabai Merah pada Musim Hujan. Agromedia Pustaka. Jakarta.

Aktar MW, Sengupta D, \& Chowdhury A. 2009. Impact of pesticides use in agriculture: their benefits and hazards. Interdiscip. Toxicol. 2(1): 1-12. 
Amalia R, Djatmiko HA, \& Soesanto L. 2004. Potensi beberapa antagonis dalam menekan Fusarium oxysporum Schlecht. f.sp. zingiberi Trujillo pada tanaman jahe. In: Soesanto L (Ed.). Prosiding Simposium Nasional I tentang Fusarium. pp. 301-312. Komda Purwokerto dan Jurusan Hama dan Penyakit Tumbuhan, Fakultas Pertanian, Universitas Jenderal Soedirman, Purwokerto.

Badan Pusat Statistik (BPS). 2015. Produksi Tanaman Sayuran Cabai Besar. http://www.bps.go.id/site/ resultTab. Accessed on 08 April 2015.

Brotman Y, Lisec J, Méret M, Chet I, Willmitzer L, \& Viterbo A. 2012. Transcript and metabolite analysis of the Trichoderma-induced systemic resistance response to Pseudomonas syringae in Arabidopsis thaliana. Microbiology 158: 139-146.

Chairul. 2003. Identifikasi secara cepat bahan bioaktif pada tumbuhan di lapangan. Berita Biologi 6(4): 621-628.

Contreras-Cornejo HA, Macías-Rodríguez L, CortésPenagos C, \& López-Bucio J. 2009. Trichoderma virens, a plant beneficial fungus, enhances biomass production and promotes lateral root growth through an auxin-dependent mechanism in Arabidopsis. Plant Physiol. 149(3): 1579-1592.

Contreras-Cornejo HA, Macías-Rodríguez L, BeltránPeña E, Herrera-Estrella A, \& López-Bucio J. 2011. Trichoderma-induced plant immunity likely involves both hormonal- and camalexin-dependent mechanisms in Arabidopsis thaliana and confers resistance against necrotrophic fungus Botrytis cinerea. Plant Signal. Behav. 6(10): 1554-1563.

Contreras-Cornejo HA, Macías-Rodríguez L, del-Val E, \& Larsen J. 2016. Ecological functions of Trichoderma spp. and their secondary metabolites in the rhizosphere: interactions with plants. FEMS Microbiol. Ecol. 92(4): 1-17.

de la Cruz J, Pintor-Toro JA, Benitez T, \& Llobell A. 1995. Purification and characterization of an endo- $\beta$-1,3-glucanase from Trichoderma harzianum that is related to its mycoparasitism. J. Bacteriol. 177(7): 1864-1871.

DeRito CM \& Madsen EL. 2009. Stable isotope probing reveals Trichosporon yeast to be active in situ in soil phenol metabolism. ISMEJ. 3: 477-485.
Elad Y, Chet I, \& Henis Y. 1982. Degradation of plant pathogenic fungi by Trichoderma harzianum. Can. J. Microbiol. 28(7): 719-725.

Heddy S. 1986. Hormon Tumbuhan. Rajawali, Jakarta.

Herwidyarti KH, Ratih S, \& Sembodo DRJ. 2013. Keparahan penyakit antraknosa pada cabai (Capsicum annuum $\mathrm{L}$ ) dan berbagai jenis gulma. J. Agrotek Tropika. 1(1): 102-106.

Kumar K, Amaresan N, Bhagat S, Madhuri K, \& Srivastava RC. 2012. Isolation and characterization of Trichoderma spp. for antagonistic activity against root rot and foliar pathogens. Indian J. Microbiol. 52(2): 137-144.

Lattanzio V. 2013. Phenolic Compounds: Introduction. In: Ramawat KG \& Mérillon JM (Eds.). Natural Products. pp. 1543-1580. Springer-Verlag Berlin Heidelberg, Berlin.

Latifah A, Kustantinah, \& Soesanto L. 2011. Pemanfaatan beberapa isolat Trichoderma harzianum sebagai agensia pengendali hayati penyakit layu fusarium pada bawang merah in planta. Eugenia 17(2): 86-94.

Lin D, Xiao M, Zhao J, Li Z, Xing B, Li X, Kong M, Li L, Zhang Q, Liu Y, Chen H, Qin W, Wu H, \& Chen S. 2016. An overview of plant phenolic compounds and their importance in human nutrition and management of type 2 diabetes. Molecules. 21(10): 1-19.

Malen PM, Kunta T, \& Rusman B. 2011. Respon petani terhadap pengendalian penyakit Fusarium oxysporum pada tanaman cabai dengan jamur Trichoderma sp. J. Agrisistem, Seri Sosek dan penyuluhan. 7(2): 76-90.

Manandhar JB, Hartman GL, \& Wang TC. 1995. Anthracnose development on pepper fruits inoculated with Colletotrichum gloeosporioides. Plant Disease. 79(4): 380-383.

Markovich NA \& Kononova GL. 2003. Lytic enzymes of Trichoderma and their role in protecting plants from fungal diseases. Prikl Biokhim Mikrobiol. 39(4): 389-400.

Nawrocka J, Szczech M, \& Małolepsza U. 2018. Trichoderma atroviride enhances phenolic synthesis and cucumber protection against Rhizoctonia solani. Plant Protect. Sci. 54(1): 17-23. 
Pakdeevaraporn $\mathrm{P}$, Wasee $\mathrm{S}$, Taylor PWJ, \& Mongkolporn O. 2005. Inheritance of resistance to anthracnose caused by Colletotrichum capsici in Capsicum. Plant Breed. 124(2): 206-208.

Prabowo AKE, Prihatiningsih N, \& Soesanto L. 2006. Potensi Trichoderma harzianum dalam mengendalikan sembilan isolat Fusarium oxysporum Schlecht. f.sp. zingiberi Trujillo pada kencur. JIPI. 8(2): 76-84.

Sandheep AR, Asok AK, \& Jisha MS. 2013. Combined inoculation of Pseudomonas fluorescens and Trichoderma harzianum for enhancing plant growth of vanilla (Vanilla planifolia). Pak. J. Biol. Sci. 16(12): 580-584.

Santoso SE, Soesanto L, \& Haryanto TAD. 2007. Penekanan hayati penyakit moler pada bawang merah dengan Trichoderma harzianum, Trichoderma koningii, dan Pseudomonas fluorescens P60. J. HPT Tropika. 7(1): 53-61.

Saravanakumar K, Li Y, Yu C, Wang Q-q, Wang M, Sun J, Gao J-x, \& Chen J. 2017. Effect of Trichoderma harzianum on maize rhizosphere microbiome and biocontrol of Fusarium Stalk rot. Sci. Rep. 7: 1-13.

Semangun H. 2007. Penyakit-Penyakit Tanaman Hortikultura di Indonesia. Gadjah Mada University Press, Yogyakarta.

Shoresh M \& Harman GE. 2008. The relationship between increased growth and resistance induced in plants by root colonizing microbes. Plant Signal. Behav. 3(9): 737-739.

Soesanto L, Sudarmono, Prihatiningsih N, Manan A, Iriani E, \& Pramono J. 2005. Potensi agensia hayati dan nabati dalam mengendalikan penyakit busuk rimpang jahe. J. HPT Tropika. 5(1): 5057.

Soesanto L, Utami DS, \& Rahayuniati RF. 2011. Morphological characteristics of four Trichoderma isolates and two endophytic Fusarium isolates. Can. J. Sci. Industrial Res. 2(8): 294-306.

Soesanto L, Mugiastuti E, \& Suyanto A. 2014. Perakitan Biopestisida Trichoderma sebagai Agensia Hayati Penyakit Tanaman untuk Meningkatkan Produksi Tanaman. Laporan Hibah Kompetensi Batch II Tahun 2014. Universitas Jenderal Soedirman, Purwokerto.
Soesanto L, Suyanto A, \& Mugiastuti E. 2015. Aplikasi metabolit sekunder dua isolat Trichoderma sp. terhadap penyakit virus cabai. Seminar Nasional Pengembangan Sumber Daya Pedesaan dan Kearifan Lokal Berkelanjutan $V$. LPPM Universitas Jenderal Soedirman, Purwokerto.

Soesanto L \& Rahayuniati. 2009. Pengimbasan ketahanan bibit pisang Ambon Kuning terhadap penyakit layu fusarium dengan beberapa jamur antagonis. J. HPT Tropika. 9(2): 130-140.

Sulistiyono FD. 2014. Ciri-ciri fisiologi dan biokimiawi beberapa isolat Trichoderma spp. yang berpotensi sebagai agensia hayati. Tesis. Universitas Jenderal Soedirman, Purwokerto.

Susilo P, Soesanto L, \& Wachjadi M. 2005. Pengaruh penggunaan fungisida sintetis dan Trichoderma sp. secara tunggal atau gabungan terhadap penyakit hawar pelepah daun padi. $J$. Pembangunan Pedesaan. V(1): 34-41.

Than PP, Prihastuti H, Phoulivong S, Taylor PWJ, \& Hyde KD. 2008. Chilli anthracnose disease caused by Colletotrichum species. J. Zhejiang Univ. Sci. B. 9(10): 764-778.

Thangavelu R \& Gopi M. 2015. Combined application of native Trichoderma isolates possessing multiple functions for the control of Fusarium wilt disease in banana cv. Grand Naine. Biocontrol Sci. Technol. 25(10): 1147-1164.

Utami U, Nisa C, Putri AY, \& Rahmawati E. 2019. The potency of secondary metabolites endophytic fungi Trichoderma sp as biocontrol of Colletotrichum sp and Fusarium oxysporum causing disease in chili. International Conference on Biology and Applied Science. AIP Conference Proceedings 2120. 080020.

Vallad GE \& Goodman RM. 2004. Systemic acquired resistance and induced systemic resistance in conventional agriculture. Crop Sci. 44(6): 19201934.

Vandenbussche F, Vriezen WH, Smalle J, Laarhoven LJJ, Harren FJM, \& Van Der Straeten D. 2003. Ethylene and auxin control the arabidopsis response to decreased light intensity. Plant Physiol. 133(2): 517-527.

Vinale F, Sivasithamparam K, Ghisalberti EL, Marra R, Woo SL, \& Lorito M. 2008. Trichoderma-plantpathogen interactions. Soil Biol. Biochem. 40(1): $1-10$. 
Vinale F, Sivasithamparam K, Ghisalberti EL, Ruocco M, Woo S, \& Lorito M. 2012. Trichoderma secondary metabolites that affect plant metabolism. Nat. Prod. Commun. 7(11): 15451550 .

Viterbo A, Ramot O, Chemin L, \& Chet I. 2002. Significance of lytic enzymes from Trichoderma spp. in the biocontrol of fungal plant pathogens. Antonie Van Leeuwenhoek. 81(1-4): 549-556.

Wachjadi M, Soesanto L, Manan A, \& Mugiastuti E. 2013. Pengujian kemampuan mikroba antagonis untuk mengendalikan penyakit hawar daun dan layu bakteri pada tanaman kentang di daerah endemis. Agrin. 17(2): 94-102.
Waller JM, Lenné JM, \& Walker SJ. 2001. Plant Pathologist's Pocketbook. CABI, Wallingford, Oxon.

Waluyo KA, Soesanto L, \& Djatmiko HA. 2005. Keefektifan tebukonazol dan Trichoderma harzianum tunggal atau gabungan terhadap tiga penyakit penting karena jamur pada padi sawah. Tropika. 13(2): 128-136.

Wardhana DW, Soesanto L, \& Utami DS. 2009. Penekanan hayati penyakit layu fusarium pada subang gladiol. J. Hort. 19(2): 199-311. 